\title{
Research on the Development Strategy of Hainan Free Trade Port International Experience and Hainan Scheme
}

\author{
Suping Zhao ${ }^{1, *}$ \\ ${ }^{1}$ School of International Business, Sichuan International Studies University, Chongqing 400031, China \\ *Corresponding author. Email: 382821096@qq.com
}

\begin{abstract}
Based on the analysis of China's free trade reform process and existing major difficulties, the paper draws lessons from the construction and operation experience of famous international free trade ports including Hong Kong, Singapore, Dubai. Finally, the development strategy of Hainan free trade port is proposed from the aspects of market legal system, government service efficiency, resource allocation efficiency, financial liberalization reform, industrial coordinated development, transportation system, talent cultivation and introduction.
\end{abstract}

\section{Keywords: free trade port, trade liberalization, financial liberalization, investment facilitation}

\section{INTRODUCTION}

Since the reform and opening up, China has embarked on a path of gradual opening up, in which pilot zones drive the remaining zones for common development. In 1979, Deng Xiaoping, the chief architect of the reform and opening up, proposed the launch of five special economic zones to explore the mode of opening up to the outside world. Subsequently, 14 state-level development zones were established in 12 coastal cities, pushing opening up further. In the 1990s, following international move, China set up bonded areas in coastal economic areas to engage in bonded logistics, bonded processing, commodity display and other businesses, which serve as the forefront of China's opening up. The 21st century witnessed China's accession to the WTO, which led to the acceleration and deepening of opening up. What's more, a series of opening modes, such as export processing zone, bonded logistics park and bonded port, survive and thrive across China. In order to further stay current with

*Fund: Youth Fund Project of the Ministry of Education "Research on the Identification and Promotion Path of China's Manufacturing Export Competitiveness from the Perspective of Global Value Chain" (Project No.: 16YJC790146), General Project of Chongqing Social Science Foundation "Research on the Coordinated Development of Chongqing's Competitive Advantage Cultivation and Export Quality Upgrading in Manufacturing Industry" (Project No.: 2018YBJJ045), Chongqing Education Commission Humanities and Social Science Project "Research on upgrading Path of Value chain of China's high-end Equipment Manufacturing Industry from multiple perspectives" (Project No.: 20SKGH126), Chongqing Municipal Education Commission Science and Technology Project "The Action Mechanism and Influence Path of Intelligent Promotion of Chinese Manufacturing Industry Value Chain" (Project No.: KJQN202000904). international market, China debuted comprehensive bonded zones in 2007, which integrated export processing, bonded logistics and other economic functions into one, greatly promoting the flow of capital and the export of goods. In 2013, China established pilot free trade zones to build an open economic system compatible with global economic integration. By 2017, China had formed 11 pilot free trade zones in three batches, including " $1+3+7 "$, to explore measures for trade and investment liberalization and facilitation reform, and to replicate and promote such move nationwide when the time is mature, thus enhancing allround opening-up. However, The Global Enabling Trade Report $2016^{1}$ takes that despite the deepening of China's opening up and the relatively significant achievements, a horizontal comparison shows that China still has many issues to be solved, which is obvious in many aspects, such as low level of trade liberalization, high import and export clearance cost, low efficiency of customs service, poor quality of logistics infrastructure, and unfavorable market economic environment. Specific indicators and their global ranking are shown in "Table I". 
TABLE I. THE LEVEL OF ECONOMIC OPENING IN CHINA

\begin{tabular}{|c|c|c|c|}
\hline First-level indicators & Second-level indicators & Numerical value & Ranking \\
\hline \multirow{4}{*}{ Level of trade liberalization } & Rate of simple average tariff on imports & $11.10 \%$ & 117 \\
\hline & Weighted average tariff rate of imports & $6.40 \%$ & 43 \\
\hline & Percentage of free trade imports & $50.20 \%$ & 95 \\
\hline & Weighted average tariff rate of export & $4.50 \%$ & 114 \\
\hline \multirow{10}{*}{$\begin{array}{l}\text { Import and export clearance } \\
\text { costs }\end{array}$} & Average cost of import documents & $170.9 \$$ & 97 \\
\hline & Review time of import documents & $65.7 \mathrm{H}$ & 88 \\
\hline & Import clearance costs & $776.6 \$$ & 120 \\
\hline & Import clearance time & $92.3 \mathrm{H}$ & 101 \\
\hline & Import clearance efficiency & 3.3 & 31 \\
\hline & Customs service index & 0.65 & 50 \\
\hline & Export document cost & $84.6 \$$ & 65 \\
\hline & Review time of export documents & $21.1 \mathrm{H}$ & 66 \\
\hline & Export clearance costs & $522.4 \$$ & 108 \\
\hline & Export clearance time & $25.9 \mathrm{H}$ & 56 \\
\hline \multirow{3}{*}{ Customs service } & Import limitation & 4.4 & 48 \\
\hline & Customs transparency & 0.9 & 40 \\
\hline & Abnormal cost of import and export & 4.3 & 53 \\
\hline \multirow{7}{*}{ Logistics infrastructure } & Air transport quality & 4.8 & 48 \\
\hline & Quality of port facilities & 4.6 & 42 \\
\hline & Quality of road transport & 4.8 & 39 \\
\hline & Postal service efficiency & 4.8 & 57 \\
\hline & Conversion efficiency of means of transport & 4.5 & 40 \\
\hline & Mobile phone service & 93.2 & 103 \\
\hline & Mobile broadband service & 56 & 62 \\
\hline \multirow{4}{*}{ Market economy environment } & Intellectual property rights (IPR) & 4.4 & 51 \\
\hline & Access to financial services & 4.3 & 45 \\
\hline & Barriers to foreign investment & 4.9 & 33 \\
\hline & Property security & 5 & 96 \\
\hline
\end{tabular}

a. Note: \$ means US dollars, H means hours. The sample of the Global Enabling Trade Report includes 136 countries

For further reform and opening up and innovative models of market economy mechanism, General Secretary Xi Jinping announced his support for building the entire island of Hainan into a free trade port with Chinese characteristics in 2018. Hainan, a pilot area for comprehensive reform and opening up, is tasked with exploring the way of factors including goods, funds, talents entering and leaving the free trade port, and drastically reforming government service, financial openness, investment facilitation, trade liberalization, talent introduction and cultivation, tax reform and construction of infrastructure, so as to serve as expanded areas of openness. There goes the issue of ways to establish Hainan free trade port. This paper summarizes the development mode and experience of internationally famous free trade ports, and proposes corresponding development strategies and suggestions based on the current situation of Hainan free trade port.

\section{THE CONSTRUCTION EXPERIENCE OF FAMOUS FREE TRADE PORTS}

Rinana on the Gulf of Genoa was named by Italy as the world's first free trade port in 1547. Subsequently, the booming of the shipping industry, the progress of communication means, and the rapid integration of world market allow export-oriented economy to contribute more to national economy. As highly free and open area for international trade and investment and financing, free trade ports is mushrooming accordingly. At present, there are more than 130 free trade ports and more than 2,000 free economic zones with similar connotations and functions around the world. International precedent shows that the free trade port policy has become an effective means to share global free trade rights and enhance international competitiveness. Hong Kong, Singapore and Dubai, among others, are typical and mature free trade ports. Although they differ in completion time, scope of opening and main functions, they do share what worth reference. For example, a developed and open financial system, preferential tax policies, free movement of people, high level of trade liberalization, investment facilitation, high-quality government services and sound laws and regulations. (See "Table II") 
TABLE II. BASIC SITUATION OF THREE FAMOUS FREE TRADE PORTS

\begin{tabular}{|c|c|c|c|}
\hline $\begin{array}{c}\text { Free } \\
\text { trade } \\
\text { port }\end{array}$ & $\begin{array}{c}\text { Completion } \\
\text { time }\end{array}$ & $\begin{array}{l}\text { Scope of } \\
\text { opening }\end{array}$ & Functions \\
\hline $\begin{array}{l}\text { Hong } \\
\text { Kong }\end{array}$ & 1842 & $\begin{array}{l}\text { Hong Kong } \\
\text { Island, } \\
\text { Kowloon and } \\
\text { New } \\
\text { Territories }\end{array}$ & $\begin{array}{l}\text { Free, diversified and } \\
\text { open economic } \\
\text { structures such as } \\
\text { finance, investment, } \\
\text { and trade }\end{array}$ \\
\hline Singapore & $1970 \mathrm{~s}$ & $\begin{array}{l}7 \text { free trade } \\
\text { zones } \\
\text { including } \\
\text { Jurong Port, } \\
\text { Changi, and } \\
\text { Airport }\end{array}$ & $\begin{array}{lr}\text { A comprehensive } \\
\text { functional } & \text { port } \\
\text { integrating } & \\
\text { warehousing, trade, } \\
\text { processing } \\
\text { finance } & \text { and } \\
\end{array}$ \\
\hline Dubai & 1985 & 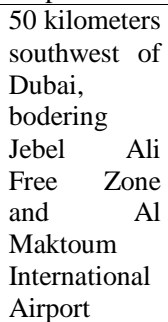 & $\begin{array}{l}\text { Integrate the } \\
\text { advantages of the } \\
\text { free trade zone and } \\
\text { the port to form the } \\
\text { largest free trade port } \\
\text { in the Middle East }\end{array}$ \\
\hline
\end{tabular}

\section{A. The unique competitiveness of a free trade port lies} in developed and open financial system

The level of financial liberalization indicates the degree of opening of free trade ports and provides financial support for the opening and development of other fields, which is mainly reflected in three aspects, namely, free capital exchange, free flow and quality services (See "Table III").

1) Free capital exchange: Hong Kong is the largest financial center in Asia and the third largest in the world. As early as 1973, Hong Kong abolished its foreign exchange control and implemented the free exchange system, which allowed the free flow of local and overseas funds in and out of Hong Kong. The gold control was obsoleted in 1974. Singapore, the world's fourth-largest financial centre, has abolished currency controls and allowed foreign companies to transfer their funds freely without paying taxes. Dubai's capital account is fully open, its trading system is dominated by US dollars, its operating environment is open and transparent, and profits can be remitted $100 \%$. But strict supervision is applied to illegal activities such as money laundering.

2) Free capital flow: In 1997, after the financial crisis in Southeast Asia, Singapore strengthened the information disclosure of its capital market, encouraged the innovation of financial products, markets and trading modes, and allowed international capital to enter and exit freely, gradually becoming the world financial trading center. In the Dubai free trade port, the safety and freedom of investors of other countries in capital exchange are fully guaranteed without any restrictions.

3) Quality financial service: Hong Kong's financial market enjoys sound legal system and market norms. Regulators supervise the market in accordance with laws and regulations, and promote the efficient operation of the market. Hong Kong enterprises adopt the international accounting standards model, and the banking network covers major cities around the world, forming an advanced trading and settlement network. The Hong Kong government supports the free and full flow of market funds and information, and provides convenient and efficient information and financial services to international investors. Singapore boasts offshore financial center, which is separated from its domestic market. Within the center, there are no statutory reserve ratio, no interest rate control, no foreign exchange control, no capital income tax, so as to promote the formation and development of an international financial center. Independent legal system and financial supervision system are employed in Dubai's free trade port, which is completely in accordance with the world financial services standards.

TABLE III. THE FINANCIAL LIBERALIZATION OF THREE FREE TRADE PORTS AND COMPARISON

\begin{tabular}{|c|c|c|c|}
\hline $\begin{array}{c}\text { Free trade } \\
\text { port }\end{array}$ & $\begin{array}{c}\text { Free capital } \\
\text { exchange }\end{array}$ & $\begin{array}{c}\text { Freedom of } \\
\text { cross-border } \\
\text { movement }\end{array}$ & $\begin{array}{c}\text { Quality } \\
\text { financial } \\
\text { services }\end{array}$ \\
\hline $\begin{array}{l}\text { Hong } \\
\text { Kong }\end{array}$ & $\begin{array}{l}\text { Free access to } \\
\text { foreign } \\
\text { exchange and } \\
\text { gold, free } \\
\text { exchange }\end{array}$ & $\begin{array}{l}\text { Funds and } \\
\text { consulting are } \\
\text { fully liquid } \\
\text { and } \\
\text { unrestricted }\end{array}$ & $\begin{array}{l}\text { Adopt } \\
\text { international } \\
\text { regulatory } \\
\text { standards and } \\
\text { focus on pre- } \\
\text { risk prevention }\end{array}$ \\
\hline Singapore & $\begin{array}{l}\text { Completely } \\
\text { abolish } \\
\text { foreign } \\
\text { exchange } \\
\text { control, } \\
\text { foreign } \\
\text { exchange can } \\
\text { be freely } \\
\text { exchanged }\end{array}$ & $\begin{array}{l}\text { No } \\
\text { restrictions on } \\
\text { the } \\
\text { repatriation of } \\
\text { income and } \\
\text { investment } \\
\text { income }\end{array}$ & $\begin{array}{l}\text { Provide } \\
\text { enterprises with } \\
\text { a full range of } \\
\text { financing } \\
\text { services, } \\
\text { especially the } \\
\text { market for } \\
\text { project } \\
\text { financing and } \\
\text { financial } \\
\text { leasing is very } \\
\text { mature }\end{array}$ \\
\hline Dubai & $\begin{array}{l}\text { Capital } \\
\text { account is } \\
\text { fully } \\
\text { convertible }\end{array}$ & $\begin{array}{l}100 \% \text { of } \\
\text { profit can be } \\
\text { remitted }\end{array}$ & $\begin{array}{l}\text { High standards } \\
\text { and full } \\
\text { transparency of } \\
\text { financial } \\
\text { business, strict } \\
\text { supervision of } \\
\text { money } \\
\text { laundering }\end{array}$ \\
\hline
\end{tabular}




\section{B. Investment liberalization is important for free trade ports to attract foreign investment}

First, investment liberalization is mainly reflected in three aspects: pre-establishment national treatment, industry opening and equity restriction. Hong Kong treats all investors alike, allowing them to invest in any industry in compliance with Hong Kong law, and there is no limit on the proportion of shares they can hold. In Singapore, foreign-funded enterprises are not subject to any restrictions on access to the commercial, foreign trade, leasing, marketing, telecommunications and other markets, but file with the local government departments is required as to finance, insurance and securities, while no involvement in defense sector is allowed. The Dubai free trade port allows foreign capital to enter and leave various industries, allows 100\% foreign-owned enterprises. Most goods are allowed to flow in and out of the free trade port, capital and profits are allowed to flow out of the country freely, and are not subject to the provisions of the UAE Company Law, nor to any financial or monetary restrictions (See "Table IV").

Second, the liberalization and facilitation of investment services is favorable. In 2007, the
Investment Promotion Agency was established in Hong Kong to provide financial services such as project financing, leveraged buyout, buyer's credit and capital settlement for foreign investment, and to provide investment information, investment fair and other services for mainland enterprises to invest and cooperate in Hong Kong, further strengthening its status as an international financial center (Zhang Shiwen and Cheng Jian, 2018). Singapore has launched incentives to encourage transnational corporations to set up business headquarters, regional commercial headquarters and regional business headquarters in the country. Policies have also been introduced to encourage local enterprises to invest abroad, such as an investment incentive scheme for overseas enterprises, a tax deduction scheme and a concessionary international trade scheme. In order to attract quality foreign investment and talents, Dubai stipulates that enterprises in the free trade port shall be exempted from corporate tax (with time limit), individual income tax, import and export tariff. There is no minimum wage, no local employment ratio is required, and long-term rental of plant and equipment is allowed. (Sun Wei, 2017)

TABLE IV. INVESTMENT LIBERALIZATION POLICIES OF THREE MAJOR FREE TRADE PORTS

\begin{tabular}{|c|c|c|c|c|}
\hline $\begin{array}{c}\text { Free trade } \\
\text { port }\end{array}$ & $\begin{array}{l}\text { Investment } \\
\text { restrictions }\end{array}$ & Industry restrictions & Equity restrictions & Foreign Service \\
\hline $\begin{array}{l}\text { Hong } \\
\text { Kong }\end{array}$ & $\begin{array}{l}\text { Local and foreign } \\
\text { investors are treated } \\
\text { equally }\end{array}$ & $\begin{array}{l}\text { Strict restrictions on the gambling } \\
\text { industry, conditional entry in } \\
\text { telecommunications, broadcasting, } \\
\text { etc. } \\
\text { Licence is required for banking, } \\
\text { insurance, etc. } \\
\text { Other industries are not restricted. }\end{array}$ & $\begin{array}{l}\text { Investors inside and } \\
\text { outside Hong Kong can } \\
\text { wholely own the } \\
\text { company }\end{array}$ & $\begin{array}{l}\text { The Investment Promotion Agency } \\
\text { was established in } 2007 \text { to provide } \\
\text { investment information, investment } \\
\text { seminars and other services for } \\
\text { investment companies }\end{array}$ \\
\hline Singapore & $\begin{array}{l}\text { The scope of } \\
\text { business of foreign- } \\
\text { capital enterprises } \\
\text { shall not be } \\
\text { restricted and } \\
\text { overseas investment } \\
\text { of domestic } \\
\text { entreprises shall be } \\
\text { encouraged }\end{array}$ & $\begin{array}{l}\text { Strict restrictions in the field of } \\
\text { national defense, financial, file to } \\
\text { the competent authorities are } \\
\text { required as to finance, insurance, } \\
\text { securities and others, and no } \\
\text { restrictions for other insuatries. }\end{array}$ & $\begin{array}{l}\text { Foreign banks are } \\
\text { prohibited from entering } \\
\text { the local retail market, } \\
\text { and foreign equity in the } \\
\text { news and broadcasting } \\
\text { industries shall not } \\
\text { exceed } 30 \% \text { and } 49 \%\end{array}$ & $\begin{array}{l}\text { Franchise international trade } \\
\text { program, commercial headquarters } \\
\text { award, business headquarters } \\
\text { award, transnational corporation } \\
\text { headquarters award and many other } \\
\text { incentive measures }\end{array}$ \\
\hline Dubai & $\begin{array}{l}\text { Foreign investment } \\
\text { are encouraged to } \\
\text { enter free trade ports }\end{array}$ & $\begin{array}{l}\text { Foreign capital is not restricted in } \\
\text { the industries it can enter }\end{array}$ & $\begin{array}{l}\text { Foreign capital can be } \\
100 \% \text { wholly owned, } \\
\text { and not subject to the } \\
\text { UAE Company Law }\end{array}$ & $\begin{array}{l}\text { Unlimited repatriation of capital } \\
\text { and profits, no minimum wage and } \\
\text { no restrictions on hiring local } \\
\text { workers }\end{array}$ \\
\hline
\end{tabular}

\section{The basic feature of international free trade port lies in free movement of manpower}

First, talent introduction can ensure the quality of free trade port construction. Guided by the philosophy of "market-oriented, employment-based and government-provided services", Hong Kong has adopted loose policy on talent introduction. The list of talents needed is released at the right time to attract talents from all over the world based on Hong Kong. Singapore has introduced a variety of work visas for workers with different degrees and skills to support talent attraction. To attract talent, Dubai free trade port has taken various measures, such as streamlining visa application process, reducing visa fees, offering visafree places, competitive tax policies and a relaxed religious environment, in a bid to attract the world's top talent involving financial and insurance, software development, architectural engineering and technical, and business management. 
Secondly, the free trade port provides a relatively complete talent training system. The Hong Kong government provides sufficient financial support and combines the characteristics of academic education and vocational education to build a lifelong learning platform for Hong Kong people. Such method can help students to complete the transition from school to society, and realize diversified ways of advancement through policy guarantee. Singapore attaches great importance to national education, especially vocational education. In-plant training, overseas training and joint training are conducted to provide support for the improvement of workers' comprehensive quality and professional ability. In addition to improving health and pension systems, Dubai government has introduced pension policy for foreign employees in the hope of attracting and retaining foreign talents.

Third, free movement of population is the basic characteristic of free trade port. Hong Kong enjoys very liberal migration policy. Foreigners are free to go to Hong Kong to participate in business, tourism or family visit. They are free to choose their occupation, enterprise and salary when looking for jobs in Hong Kong. Singapore and Dubai also offer policies to encourage migration(See "Table V").

TABLE V. TALENT POLICY OF THREE FREE TRADE PORTS

\begin{tabular}{|l|l|l|l|}
\hline \multicolumn{1}{|c|}{$\begin{array}{c}\text { Free trade } \\
\text { port }\end{array}$} & \multicolumn{1}{|c|}{ Talent introduction } & \multicolumn{1}{c|}{ Talent mobility } & Talent cultivation \\
\hline Hong Kong & $\begin{array}{l}\text { Loose talent introduction policy. } \\
\text { Recruiting talents from all over the } \\
\text { world with Hong Kong as basis }\end{array}$ & $\begin{array}{l}\text { It is very convenient for } \\
\text { foreigners to travel to Hong } \\
\text { Kong, visit relatives and } \\
\text { engage in business activities }\end{array}$ & $\begin{array}{l}\text { Employers choose their employees } \\
\text { freely, determine their own salary, and } \\
\text { the Hong Kong government builds a } \\
\text { lifelong learning platform }\end{array}$ \\
\hline Singapore & $\begin{array}{l}\text { Workers of all levels of education and } \\
\text { skills are free to obtain different types } \\
\text { of visas }\end{array}$ & $\begin{array}{l}\text { The international population } \\
\text { is highly mobile }\end{array}$ & $\begin{array}{l}\text { Formal and vocational education has } \\
\text { been given high priority to train all } \\
\text { kinds of talents }\end{array}$ \\
\hline pubai & $\begin{array}{l}\text { Attracting talents by simplifying visa } \\
\text { preferential tax policies and a relaxed } \\
\text { religious environment }\end{array}$ & $\begin{array}{l}\text { Population mobility is } \\
\text { relatively high }\end{array}$ & $\begin{array}{l}\text { Improve medical insurance } \\
\text { endowment insurance systems, and } \\
\text { provide pension policies for employees } \\
\text { of other countries }\end{array}$ \\
\hline
\end{tabular}

\section{Free trade port is mostly defined by sound liberalization and facilitation of trade and goods}

First, the level of liberalization of trade in goods within the free trade port is very high. As world famous free port, Hong Kong adopts legal control on dangerous drugs, firearms, animals and plants, endangered species, meat and poultry, etc., but other commodities are not subject to control, such as the type, price and trade body. Import and export trade (including the types of import and export commodities, the price of import and export commodities, the identity of the trading subject and the choice of the import and export market, etc.) enjoys a wide range of free space. Singapore implements free trade policy, and leads the world in trade liberalization, which is highlighted in free establishment of trade operators. Enterprises in the area are allowed to engage in import, export and transshipment business after registering with the Accounting and Enterprise Administration bureau and applying for central registration number from the Customs Bureau.

Second, the level of trade facilitation in free trade port is very high. Hong Kong, a free trade port, boasts simple and convenient import and export procedures, and no customs restrictions on means of transport entering or leaving the customs or on loading, unloading, transshipment and storage of transhipment cargo in the port. The inspection, quarantine and border control departments of the port only conduct routine inspections on ships and crew members. In addition, diverse trade settlement methods and channels are accepted. Hong Kong ranks fourth across the globe for cross-border trade facilitation according to Doing Business 2019 released by World Bank, two places below Singapore. Thanks to concession international shipping and maritime finance preferential program, Singapore government has greatly lowered the tax and fee costs of shipping enterprises and service industries concerned. As a result, a complete industrial chain covering shipping information and trading, ship brokerage and maintenance, maritime training and others is established. Information technology and networking tools have also been taken to establish a "single window" service system. (Zhang Shiwen, Cheng Jian, 2018) In this way, trade facilitation, efficient regulation and high-quality services are secured, and Singapore gradually become an international shipping center, laying a solid foundation for international trade and investment. Dubai, the hub of economic activity in Europe and Asia, allows most goods to move freely in and out of the port. Import and export examination and approval procedures, visas, etc. can be done within 24 hours, foreign exchange transactions are not controlled, and the settlement of foreign trade enterprises is not subject to any financial or monetary restrictions (See "Table VI"). 
TABLE VI. TRADE LIBERALIZATION AND FACILITATION POLICIES OF THE THREE MAJOR FREE TRADE PORTS

\begin{tabular}{|c|c|c|c|c|}
\hline $\begin{array}{c}\text { Free trade } \\
\text { port }\end{array}$ & Tariffs & Non-tariffs & Settlement & Shipping \\
\hline Hong Kong & $\begin{array}{l}\text { A tariff-free policy is adopted } \\
\text { for commodities other than } \\
\text { alcoholic drinks, methanol, } \\
\text { hydrocarbon oil and tobacco. }\end{array}$ & $\begin{array}{l}\text { Articles other than dangerous drugs, } \\
\text { firearms, animals and plants, } \\
\text { endangered species, meat and } \\
\text { poultry are not subject to control. }\end{array}$ & $\begin{array}{l}\text { The settlement is } \\
\text { free with } \\
\text { diversified } \\
\text { channels. }\end{array}$ & $\begin{array}{l}\text { The entry and exit of means } \\
\text { of transport are not subject } \\
\text { to customs restrictions and } \\
\text { clearance. }\end{array}$ \\
\hline Singapore & $\begin{array}{l}\text { A tariff-free policy is adopted } \\
\text { for commodities other than } \\
\text { alcoholic drinks, tobacco, } \\
\text { petroleum products, and } \\
\text { automobiles. }\end{array}$ & $\begin{array}{l}\text { Three platforms, the trade } \\
\text { Information network, the port } \\
\text { information network and the dock } \\
\text { operating system, have been } \\
\text { established to facilitate trade and } \\
\text { make regulation more efficient. }\end{array}$ & $\begin{array}{l}\text { Free trade } \\
\text { settlement, free } \\
\text { choice of currency }\end{array}$ & $\begin{array}{l}\text { As international shipping } \\
\text { centers, taxes and fees for } \\
\text { shipping enterprises and } \\
\text { service industries are } \\
\text { greatly reduced. }\end{array}$ \\
\hline Dubai & $\begin{array}{l}\text { No tax shall be levied on } \\
\text { storage, trade or processing } \\
\text { within the area. }\end{array}$ & $\begin{array}{l}\text { Random check is employed for } \\
\text { supervision. Company is exempt } \\
\text { from income tax for } 5 \text { years and } \\
\text { value-added tax for } 50 \text { years. }\end{array}$ & $\begin{array}{l}\text { Trade settlement } \\
\text { is free from } \\
\text { financial and } \\
\text { monetary } \\
\text { restrictions. }\end{array}$ & $\begin{array}{l}\text { An important fulcrum of } \\
\text { East-West communication, } \\
\text { and the center of Eurasian } \\
\text { economic activities }\end{array}$ \\
\hline
\end{tabular}

\section{E. The success of a free trade port cannot be achieved without quality government service and efficiency}

First, the power of government is clearly defined. Hong Kong government follows the principle of "big market, small government" as to economic operation. The basic role of market mechanism in resource allocation is given full play, and government's interference into economy is kept at the minimum extent. No government agency can be found in the free trade port of Singapore. Professional companies under the supervision of government is responsible for management, which is loose but flexible. Dubai government took the initiative to cede certain administrative power and set up Abu Dhabi Port Authority, which oversees the work of customs, banking, posts and telecommunications, transportation, security and other administrative services. The department shoulders port infrastructure construction within the port, while performs government functions outside the port, providing one-stop and efficient service for enterprises. This is the trick to the success of Dubai free trade port.

Secondly, the market access standards have been clarified. The laws of the Hong Kong Special Administrative Region stipulates no limitation on the registered capital and available funds of new companies, and capital verification is not required. The general meeting of shareholders may also decide whether to increase the registered capital by means of resolution after the establishment of the company. In the free trade port of Singapore, the government has relatively relaxed requirements for enterprises' access and will not interfere in their daily business activities. Banking, finance, insurance, securities, communications, and industries that negatively affect environment need to apply to local authorities for business licenses. In addition to the above industries, other new business institutions and companies can engage in business as long as they register with the Business Registration Bureau.

Thirdly, the establishment of efficient serviceoriented government. Government of Hong Kong boasts sound service and standard regulation. All investments, whether inside or outside China, are entitled to national treatment. New businesses registered in Hong Kong can obtain corporate license through only three steps. The operation and management of enterprises in the region must comply with the Company Law, Banking Ordinance and other laws and regulations, and also subject to the nongovernmental self-regulatory organization as trade council and chamber of commerce. Thanks to its excellent business environment, simple registration procedures and low fees, Singapore has attracted a large number of multinational companies. The requirements for registered enterprises in Singapore are less onerous: an adult of 18 years of age or above of any nationality may complete the registration by providing only registered address in Singapore, the name of the company, its articles and by-laws, identification of legal person and office hours form. The appointment of a Singapore director and a local secretary is also included. (Hu Yaolei, Hu Dening, 2018) Dubai government values advisory services provided to enterprises to help them obtain cheap financing and solve the problems encountered in operation as soon as possible(See "Table VII"). 
TABLE VII. MARKET ACCESS AND GOVERNMENT SERVICE OF THE THREE MAJOR FREE TRADE PORTS

\begin{tabular}{|c|c|c|c|}
\hline $\begin{array}{c}\text { Free trade } \\
\text { port }\end{array}$ & Scope of authority & Market access & Service efficiency \\
\hline Hong Kong & $\begin{array}{l}\text { The government's power is } \\
\text { limited as little as possible and } \\
\text { the policy of active non- } \\
\text { intervention is launched. }\end{array}$ & $\begin{array}{l}\text { Foreign investment enjoys } \\
\text { "national treatment" to ensure full } \\
\text { and free competition among the } \\
\text { market. }\end{array}$ & $\begin{array}{l}\text { Loose business registration } \\
\text { conditions, simple and convenient } \\
\text { procedures, standard and efficient } \\
\text { government service }\end{array}$ \\
\hline Singapore & $\begin{array}{l}\text { No administrative management } \\
\text { shall be imposed on the } \\
\text { enterprise, and daily supervision } \\
\text { shall be conducted according to } \\
\text { law. }\end{array}$ & $\begin{array}{l}\text { The comprehensive business } \\
\text { environment is excellent, ranking } \\
\text { first across the globe for eight } \\
\text { consecutive years. }\end{array}$ & $\begin{array}{l}\text { Simple enterprise registration } \\
\text { procedures and low costs that } \\
\text { drum up a large number of } \\
\text { multinational enterprises. }\end{array}$ \\
\hline Dubai & $\begin{array}{l}\text { Abu Dhabi Port Authority is set } \\
\text { up to provide one-stop service. }\end{array}$ & $\begin{array}{l}\text { No restriction on foreign capital } \\
\text { entry and capital exchange. }\end{array}$ & $\begin{array}{l}\text { Customs clearance procedures and } \\
\text { visas can be completed within } 24 \\
\text { hours, and investment approval } \\
\text { procedures can be completed } \\
\text { within } 7 \text { days. }\end{array}$ \\
\hline
\end{tabular}

\section{F. The effective operation of free trade port is} impossible without mature and stable market law

Hong Kong's free port is based on a highly mature market law. There are more than 1,000 existing laws and regulations and subsidiary regulations, among which economic regulations account for about $45 \%$. Moreover, they are constantly supplemented, amended and improved to protect enterprises' economic activities.

Singapore enjoys a complete economic legal system. Based on the British legal system, a system covering the Constitution, act of congress and subsidiary regulations, judicial precedents and legal practices is formed. Among them, the Free Trade Zone Law involves the positioning, function, management system, preferential system and supervision system of the free trade zone. The preferential system covers tax exemption, income tax and other tax reduction and exemption, investment access, customs system, labor policy, land system and others. Corporate Law, Labour And Employment Act, Environmental Protection Act, Foreign Trade Act on Commodities, Tax Act on Goods and Services, Customs Act, Merchant Shipping Act, and Strategic Materials Control Act mainly include scope and powers of administration as to industry and commerce, health, environmental protection and others, and liability shall be pursued in accordance with the law on enterprises (Zhang Shiwen, Cheng Jian, 2018).

An independent legal system was applied within Dubai free trade zone. In 2004, Dubai enacted the Financial Free Zones Act, which allows emirate's government to establish financial free zones locally. Within the zone, there will be no corporate income tax, no individual income tax, no import and export duty and no re-export duty for 50 years. No tax will be levied on storage, trade, processing and manufacturing in the zone. The courts of Dubai free trade zone enjoys specific exclusive jurisdiction over all civil and commercial disputes within the financial hub, disputes relating to registered institutions and companies within the centre, as well as cases in which the parties wish to be heard by courts in other recognized jurisdictions(See "Table VIII").

TABLE VIII. THE RULE OF LAW OF THREE FREE TRADE PORTS

\begin{tabular}{|l|l|l|}
\hline $\begin{array}{c}\text { Free trade } \\
\text { port }\end{array}$ & \multicolumn{1}{|c|}{$\begin{array}{c}\text { Laws and } \\
\text { regulations }\end{array}$} & $\begin{array}{l}\text { Law enforcement } \\
\text { efficiency }\end{array}$ \\
\hline Hong Kong & $\begin{array}{l}\text { Sound legal system } \\
\text { and mature market } \\
\text { economy }\end{array}$ & $\begin{array}{l}\text { A open and fair } \\
\text { operating } \\
\text { environment }\end{array}$ \\
\hline Singapore & $\begin{array}{l}\text { Free Trade Zone } \\
\text { Law }\end{array}$ & $\begin{array}{l}\text { The government } \\
\text { shoulder supervision } \\
\text { in accordance with } \\
\text { the law and } \\
\text { investigate liability } \\
\text { for violations }\end{array}$ \\
\hline Dubai & $\begin{array}{l}\text { No tax shall be } \\
\text { levied on storage, } \\
\text { trade or processing } \\
\text { within the area. } \\
\text { employed check is } \\
\text { supervision. } \\
\text { Company is exempt } \\
\text { from income tax for } \\
5 \text { years and value- } \\
\text { added tax for 50 } \\
\text { years. }\end{array}$ \\
\hline
\end{tabular}

\section{G. Preferential tax policies drives the construction of free trade ports}

Singapore adopts unified corporate income tax policy for domestic and foreign enterprises, with a corporate tax rate of $17 \%$. Goods other than tobacco, alcohol, oil and motor vehicles are exempt from customs duties. There is no tax office in the Dubai free trade port. Tariffs of $5 \%$ are only levied on general imported goods, duties are exempted on transit goods, and enterprises in free trade ports are exempted from 
enterprise income tax for 50 years. Hong Kong exempts imports and exports of general goods except cigarettes, alcohol, methanol and hydrocarbon oil.

\section{LEARNING FROM INTERNATIONAL EXPERIENCE}

Based on the experience in the construction and operation of Hong Kong, Singapore, Dubai and other advanced and mature free trade ports, as well as China's reality, the author takes that the establishment of a free trade port with Chinese characteristics requires breakthroughs or innovations in the following aspects.

\section{A. Expanding the scope of tax incentives}

The construction of free trade port requires innovation in tax system and collection and management. The operating cost of enterprises can be reduced, and the efficiency of tax collection can be improved to drive the development of enterprises in the port. On the basis of the preferential policies, free trade port enjoys less tax categories, lower tax rates and better tax incentives. In addition, legislation is adopted to ensure the openness and transparency of tax collection, and written agreements are signed with enterprises to implement preferential tax arrangements.

\section{B. Optimizing government management system}

As to the construction of free trade ports, government takes the role more of server than administrator. Administrative examination and approval process has been streamlined, and measures such as multi-card in one have been introduced to serve the people better. The financial leasing system are also improved to provide policy and financial support for port business activities. The market economic system is enhanced to create a level environment for market entities. Finally, double efforts are made to reduce negative list, allowing local governments greater autonomy to attract investment.

\section{Improving market economy system}

A sound market economy system goes a long way towards free flow and effective allocation of personnel, finance, logistics and public services. The work permit system for foreigners in China should be standardized to provide visa and entry and exit facilitation measures for talents. The free import and export of resources needed by enterprises and the free flow of capital should be guaranteed to realize the efficient allocation of factors. In addition, a perfect transportation network, speedy customs clearance procedures and transparent charging mode should be established to lower the logistics cost, trade cost and uncertainty of enterprises.

\section{Advancing reform of financial system}

Exchange control on capital account is gradually petered, onshore finance and offshore finance are separately supervised, the free flow of capital, such as investment, profits and dividends, etc. of foreign-capital enterprise is prioritized, and convenient exchange business and capital turnover services are provided. With risk kept under control, the free flow of securities and investment is gradually liberalized, and financial mode and product innovation are encouraged, thus establishing an international financial center.

\section{DEVELOPMENT STRATEGY OF HAINAN FREE TRADE PORT}

\section{A. Construction status of Hainan free trade port}

Hainan guards the gateway of the South China Sea and faces Vietnam, the Philippines, Indonesia, Malaysia, Singapore, Thailand, Papua New Guinea, Australia and Brunei across the sea. It is China's strategic hub connecting ASEAN and Oceania, and a key node of the Maritime Silk Road. In the new era, Hainan free trade port is China's strategic fulcrum connecting ASEAN, Australia, South Asia and Africa. The string of pearls of ports became a hub for goods, capital, information and talent between China and countries along the Maritime Silk Road. (Li Dongyan, 2009) Although Hainan's land area is only 35,400 square kilometers, the whole land area including sea area reaches 2.035 million square kilometers, which is 35 times the size of Hong Kong, 50 times the size of Singapore and 10 times the size of Dubai, making it the largest province in China. Hainan has a population of 9.26 million, 1.25 times that of Hong Kong, 1.65 times that of Singapore and 3 times that of Dubai. Therefore, unique geographical location, rich and diverse natural resources, huge human resource reserve and extremely important strategic position make Hainan a perfect place for free trade port.

According to Haikou's customs statistics, the value of Hainan's imports and exports reached 84.9 billion yuan in 2018, up 20.8 percent year-on-year and 11.1 percent higher than the national growth rate. The overall scale is rising quarter by quarter, with the eastern and western regions enjoying a similar scale. Among them, the eastern region is developing rapidly, with an import and export scale of 42.42 billion yuan, a growth rate of up to $50.5 \%$, showing huge potential. Hainan has trading partners in 161 countries and regions, among which ASEAN, the United States and the European Union are the top 3. In 2018, the total import and export value of Hainan to countries along the Belt and Road Initiative was 31.91 billion yuan, accounting for $37.6 \%$ and growing by $0.6 \%$. Among them, Turkey, Egypt and India saw the fastest growth 
rates, increasing by 2 times, 1.9 times and $51.7 \%$, respectively.

\section{B. Suggestions on developing strategies for Hainan to build free trade port}

The first is to improve the laws and regulations As the special economic zone and the reform pilot, Hainan free trade port follows certain policy and measure that is in conflict with the general laws and regulations in China. To ensure the policies and implementation of relevant laws of free trade port, laws and regulations corresponding to its status and supporting policies and regulations should be established, so as to ensure that the establishment, operation, management and trail of free trade port can be governed by laws.

The second is to innovate the tax system and attract advanced resources Advanced and sufficient resources and factors are crucial to the high-quality development of free trade port. To attract top elements from all over the world and get them settled in Hainan requires reforming the tax system and establishing a competitive tax environment. Transit goods are exempt from customs and import value-added tax, VAT is reduced or exempted for legal persons in the area, and income tax is reduced for individuals. The interest withholding tax of overseas financial institutions should be abolished step by step to promote the establishment and development of regional financial service centers. Hainan's regional connections with South-east Asian countries should be employed to encourage multinational companies in the region to move their headquarters or regional centres to Hainan. The tax refund system of port of departure should be launched to make Hainan a more attractive free trade port and an international shipping center.

The third is to provide quality services and improve regulatory efficiency The "One Network, All Can Be Handled" practiced in Shanghai and "electronic business license" of Tianjin ${ }^{2}$ should be followed to establish a commercial registration system, reduce enterprise registration and change, and improve enterprise operation efficiency. The enterprise registration information and credit information sharing platform should be taken into effect to provide free information consultation, inquiry service, information disclosure and resource sharing for enterprise. Government coordination capability should be given full play to provide a communication platform for enterprises, especially a communication platform concerning supply chain management and financing for innovative enterprises. The negative list should be further reduced, especially in the service sector. Efforts

On April 12, 2018, Shanghai implemented all-in-service system for government affairs, making it possible to finish through one trip. Tianjin issued the first batch of new standard electronic business license in China. should be made to attract excellent arbitration institutions in other countries to settle in Hainan and fully implement pre-establishment national treatment and negative list management system.

The fourth is to pilot financial innovation and establish a financial center Attention should be paid to attract financial enterprises to Hainan, especially export-oriented financial institutions such as AIIB (Asian Infrastructure Investment Bank) and Silk Road Foundation to build a financial service center for countries along "the Belt and Road Initiative" and the whole world. Competent foreign-funded commercial bank, securities institutions, investment bank, insurance companies and other financial institutions should be allowed to locate in Hainan. On the premise that financial risks are under control, negative list businesses should be reduced and foreign financial institutions should be encouraged to set up regional financial centers through tax incentives and other means. Exchange control on capital account should be relaxed, especially for the legal business of financial institutions, so as to remove obstacles for the construction of financial centers. The competitiveness and risk of Internet finance should be clarified to provide convenient and efficient financial services for enterprises in the port in such fields as intelligent contract, micro-credit, payment and settlement, investment management, transaction data analysis and encrypted asset custody.

The fifth is to promote the development of ports and establish distribution centers In view of Hainan's location, cooperation between airports and seaports should be strengthened, multi-modal transport should be innovated, and an international logistics hub facing the Pacific Ocean, Indian Ocean and Southeast Asia should be built. Modern international logistics service should be actively developed to promote the extension of industrial chain, realize the interconnection between logistics and capital flow, information flow and technology flow, as well as the coordinated development of offshore trade and onshore trade, logistics and settlement. Logistics integration within the port should be improved, the speed of customs clearance for import and export goods should be accelerated, the development of transit business should be promoted, and high-quality logistics services should be provided to enterprises in the port area with the lowest cost and the highest efficiency. An internationally competitive shipping development model should be explored to build an international cargo distribution center based on the advantages of maritime Belt and Road and the huge domestic import and export market scale.

The sixth is to innovate talent mechanism and establish information center. Talent and information serve as the most important resources of the $21 \mathrm{st}$ 
century. A free trade port is a highly free economic zone, including the free flow of people, goods, capital and information in the fields of trade, investment and finance and the free allocation of high-end elements (including capital and talents). The construction of such zone requires comprehensive professionals with solid foundation, broad vision, rich knowledge and advanced thinking. Cutting-edge technologies such as big data, cloud computing and artificial intelligence therefore can be employed to aggregate and analyze information, providing intellectual support and guarantee for the construction of international cargo distribution center and financial center. As a result, efforts should be made to cultivate, attract and retain talents, establish and improve talent security system, nurture the competitiveness of system, and maintain the innovative vitality and sustainable development of free trade port.

\section{CONCLUSION}

This paper analyzes the progress, stages and achievements of China's foreign trade liberalization reform since the reform and opening up. The Global Enabling Trade Report 2016 is also employed to analyze the major challenges facing China in terms of trade liberalization, import and export clearance costs, customs service, logistics infrastructure, and market economy environment. The experience of Hong Kong, Singapore, Dubai and other internationally famous free trade ports in the construction and operation of financial liberalization, investment facilitation, trade liberalization, population movement facilitation, efficient government services, effective market mechanism, and tax system competitiveness are also elaborated in this paper. Finally, the development status and vision of Hainan free trade port is also taken into consideration in the paper to propose development strategies concerning the laws and regulations of market operation, innovation of tax system and mechanism, efficiency of government service and supervision, pilot finance opening up and innovation, the construction of international logistics center, and the introduction and cultivation of innovative talents.

\section{References}

[1] Li Meng. The Analysis and Relevant Suggestions for China Free Trade Port's Policy Innovation in the New Era [J]. Shanghai Economic Review, 2018 (05): 60-71. (in Chinese)

[2] Tian Zhen. The strategic significance and development measures of China's construction of a free trade port [J]. International Economic Cooperation. 2017 (12): 29-34.375. (in Chinese)

[3] Zhu Fulin. The Current Situation, Development Trend and Experience Reference of Modern Free Trade Ports in the World [J]. Lanzhou Academic Journal, 2018 (11): 144-153. (in Chinese)

[4] Pei Changhong, Liu Bin, Li Yue. Exploration on the Development Model of Free Trade Port with Chinese
Characteristics [J]. International Business (Journal of University of International Business and Economics), 2019 (01): 1-10. (in Chinese)

[5] Li Kaijie. Research on the transformation of China's pilot free trade zone to a free trade port [J]. International Economic Cooperation. 2017 (12): 35-39. (in Chinese)

[6] Zhu Mengnan, Chen Chong, Zhu Huijun. From Free Trade Zone to Free Trade Port: International Comparison and China's Choice - Analysis of the Construction Xiamen Free Trade Port [J]. Financial Forum, 2018, v.23; No.269(5): 5-14. (in Chinese)

[7] Research Group of the Chinese Academy of International Trade and Economic Cooperation. Ministry of Commerce. Comparison and Reference of Free Port Policy between Shanghai FTA and Hong Kong, Singapore [J]. Scientific Development, 2014 (9): 5-17. (in Chinese)

[8] Zhu Caihua, Li Guanghui, Bai Guangyu. China's goal of building a free trade port and related suggestions $[\mathrm{J}]$. Internade. 2018 (03): 9-15. (in Chinese)

[9] Wang Sheng, Liu Congyong, Zhang Dongdong. The enlightenment of the development of Dubai Free Trade Port Zone to Hainan [J]. Hainan Today Magazine, 2018 (07): 17-19. (in Chinese)

[10] $\mathrm{Hu}$ Yaolei, $\mathrm{Hu}$ Dening. International experience and implementation suggestions for the construction of free trade ports in developing countries [J]. Practice in Foreign Economic Relations and Trade, 2018 (08): 85-88. (in Chinese)

[11] Zhang Shiwen, Cheng Jian. Thoughts on the construction of a national free trade port [J]. China Business and Market, 2018, 32 (02): 91-97. (in Chinese)

[12] He Yaoming. On the key points and difficulties of the legalization of the business environment of Hainan Free Trade Port [J]. China Market, 2019 (16): 76-77 + 79. (in Chinese)

[13] Li Dongyan. The Effects of Free Trade Zone on the Regional Economy [D]. Tianjin University of Finance and Economics, 2009. (in Chinese)

[14] Sun Wei. Research on the Function of Free Trade Zone [D]. Liaoning University, 2017. (in Chinese)

[15] Cao Xiaolu, Wang Chongmin. On the Innovation of Temporary Arbitration System in Building Hainan into a Free Trade Por [J]. Humanities \& Social Sciences Journal of Hainan University, 2018, 36 (03): 1-7. (in Chinese) 